\title{
Article
}

\section{Description of Parenting Patterns on Stunting and Normal Children in the Specific Area Stunting of Pasaman and West Pasaman District, West Sumatra}

\author{
Dr. dr. Masrul, M.Sc., SpGK $K^{l}$ \\ ${ }^{1}$ Department of Nutrition, Faculty of Medicine, Andalas University
}

\section{SUBMISSION TRACK}

Recieved:

Final Revision:

Available Online:

KEYWORDS

Stunting, specific area of stunting, parenting, intake

CORRESPONDENCE

Phone: $\operatorname{xxxxxxxxxxx}$

E-mail:

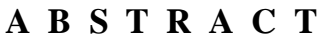

\begin{abstract}
Stunting is the effect of a systemic condition of chronic malnutrition which affects about a quarter of children under five years of age worldwide. There are 7.6 million (37\%) Indonesian children suffering from stunting and the rate of stunting in West Sumatra is above the national figure of $46.1 \%$. That number shows that many children need more attention, because they don't grow well. The nutrition intervention program that has been running so far has not been able to optimally improve the condition of stunting children. The purpose of this study was to determine the profile of parenting stunting and the difference with normal children in the specific area of stunting Pasaman and Pasaman Barat District. This study was conducted through several stages, which is data collection using a questionnaire. From this study shown that breastfeeding and complementary feeding are almost no different from groups stunting with normal children; good parenting, health and psychosocial stimulation are still lacking; the socioeconomic level of stunting children is lower than normal children. It is hoped that in the future prevention of intrautrin can be carried out by maintaining quality intake and health status; keep the intake in a balanced nutritional status, especially aspects of animal protein; and maintaining environmental sanitation and optimal parenting from the family.
\end{abstract}

\section{INTRODUCTION}

Stunting affects about a quarter of children under five years of age worldwide. Stunting is the effect of a systemic condition with chronic malnutrition. Childhood stunting can develop during the first two years of life and is largely caused by nutritional deficiencies and infectious diseases (Black et al., 2013). In 2014, there were an estimated 159 millionchildren stuntingwho almost all lived in low-income countries (Black et al., 2013, Semba et al., 2016, UNICEF /World Health Organization/ World Bank Group, 2015). Data from the Indonesian Ministry of Health in 2013 reported that there were 7.6 million $(37 \%)$ Indonesian children suffering from stunting. The number ofpatients stunting in West Sumatra is above the national figure of $46.1 \%$. That number shows that many 
children need more attention, because they don't grow well. (RISKESDAS, 2013)

Stunting has long-term effects such as decreased survival rates, impaired cognitive and motor development, decreased economic productivity, and a higher chance of living in poverty in adulthood (Black et al., 2013, Grantham-McGregor et al., 2007). WHO has set a global reduction target of $40 \%$ of children under five stunted in 2025 (de Onis et al., 2013). The reduction in stunted children is included in the United Nations Sustainable Development Goal \# 2 (Murray, 2015).

The nutrition intervention program that has been running so far has not been able to optimally improve the condition of stunted children. The results of observations, analysis and modeling of nutrition intervention programs from 34 countries showed that the implementation of 10 evidence-based nutritional interventions namely folic acid supplementation, balanced protein supplementation for mothers, calcium supplementation for mothers, multiplesupplementation smicronutrient during pregnancy, promotion of breastfeeding, supplementary feeding sufficient, the provision of vitamin $\mathrm{A}$ and zinc supplementation with a coverage rate of $90 \%$ the results were only able to reduce therate stunting by $15 \%$ (Bhutta et al., 2013). This number is far from an international goal to reduce stunting. The low understanding of molecular pathogenesis and the mechanism ofmetabolism stunting contribute to the effectiveness of nutritional interventions in improving and pursuing the growth ofchildren stunting.

Parenting, health, clean, hygiene will indirectly affect the nutritional status of children, parenting is manifested in several activities usually carried out by mothers including breastfeeding and MP-ASI, further stated, care is influenced by the availability of resources in the household including education, knowledge, maternal health and social support (Engle et al., 1997).

The practice of psychosocial care is defined as the behavior practiced by caregivers (mothers, fathers, grandmothers, or other people) in providing food, maintaining health, providing stimulus and emotional support needed by children for growth and development processes (Brooks et al., 2011).

This study is one part of a large study through the collaboration between the Directorate of Nutrition of the Indonesian Ministry of Health and the Faculty of Medicine of Andalas University in 2018 regarding the intervention package on nutrition issues and the application of the first 1000 days of life at thespecific area stunting in Pasaman and West Pasaman districts of West Sumatra province with the number contract KN01.01 / 2/1302/2018 and 2655 / UN.16.2 / TU / 2018 dated 6 April 2018.

This study was aimed to determine the profile of parenting stunting and difference with normal children in the specific area of stunting Pasaman and West Pasaman District.

\section{METHODS}

This was quantitative study using a cross sectional design, data on independent variables and dependent variables are collected and assessed at a time. This study was conducted on 185 children aged 0-3 years, consisting of groups of stunting 94 respondents and not stunting 91 respondents.

\section{RESULTS AND DISCUSSION}

\subsection{Respondent Characteristics}

Characteristics of respondents in this study can be seen as follows.

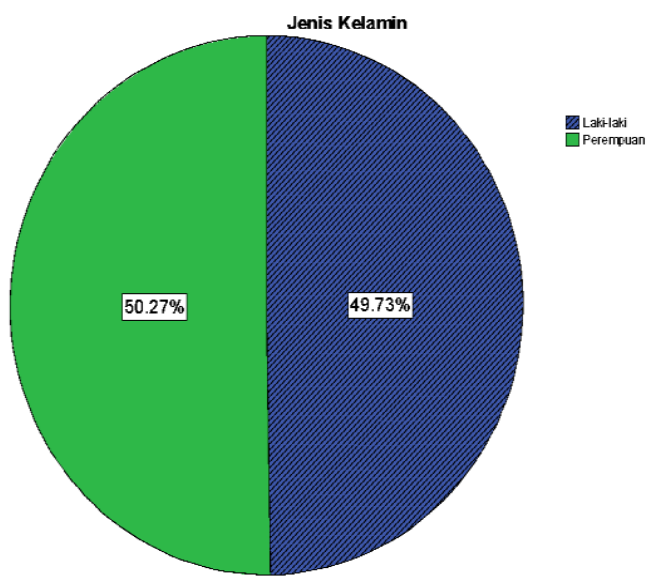

Figure 1. The picture of the sex of the child 
Figure 1 shows that more than half of the

\begin{tabular}{|c|c|c|c|}
\hline \multirow[b]{2}{*}{ Variable } & \multicolumn{2}{|c|}{ Nutritional Status } & \multirow[b]{2}{*}{$\begin{array}{c}\text { p- } \\
\text { value }\end{array}$} \\
\hline & $\begin{array}{l}\text { Stunting } \\
(\mathrm{n}=94)\end{array}$ & $\begin{array}{l}\text { Normal } \\
(\mathrm{n}=91)\end{array}$ & \\
\hline Immunization & & & 0.329 \\
\hline Complete & $88(93.6)$ & $88(96.7)$ & \\
\hline Incomplete & $6(6.4)$ & $3(3.3)$ & \\
\hline Vitamin $\mathrm{A}$ in & & & \\
\hline February & & & 0.595 \\
\hline Already & $93(98.9)$ & $89(97.8)$ & \\
\hline Not at all & $1(1.1)$ & $1(1.1)$ & \\
\hline $\begin{array}{l}\text { Age is not enough } \\
\text { when the month } \\
\text { Vitamin A }\end{array}$ & $0(0)$ & $1(1.1)$ & \\
\hline
\end{tabular}

respondents (50.27\%) were male and less than half of the respondents $(49.73 \%)$ were female.

Table 1. Characteristics of children

\begin{tabular}{|c|c|c|c|}
\hline \multirow[b]{2}{*}{ Variable } & \multicolumn{2}{|c|}{ Nutritional Status } & \multirow[b]{2}{*}{$\begin{array}{c}p \\
\text { value }\end{array}$} \\
\hline & $\begin{array}{c}\text { Stunting } \\
(\mathrm{n}=94)\end{array}$ & $\begin{array}{l}\text { Normal } \\
(\mathrm{n}=91)\end{array}$ & \\
\hline $\begin{array}{l}\begin{array}{l}\text { Age of } \\
\text { child } \\
\text { (month), } \\
\text { mean } \pm \text { SD }\end{array}\end{array}$ & $23.97 \pm 6.74$ & $24.44 \pm 6.95$ & 0.640 \\
\hline $\begin{array}{l}\text { Infant birth } \\
\text { weight } \\
\text { (gram), } \\
\text { mean } \pm \text { SD }\end{array}$ & $\begin{array}{c}3284.04 \pm \\
480.65\end{array}$ & $\begin{array}{c}3210.88 \pm \\
478.83\end{array}$ & 0.301 \\
\hline $\begin{array}{l}\text { Infant birth } \\
\text { length } \\
\text { (cm), mean } \\
\pm \text { SD }\end{array}$ & $41.54 \pm 16.80$ & $46.93 \pm 8.85$ & $\begin{array}{c}0.007 \\
*\end{array}$ \\
\hline $\begin{array}{l}\text { Birth order } \\
\text { of the child, } \\
\text { mean } \pm \mathrm{SD}\end{array}$ & $2.56 \pm 1.54$ & $2.60 \pm 1.44$ & 0.854 \\
\hline
\end{tabular}

Table 1 shows that there is a relationship between infant birth length and incidence of stunting ( $p<0.05)$. But there was no correlation between age, birth weight, birth order of children with the incidence of stunting ( $p>0.05)$.

\subsection{Feeding Patterns}

An overview of parenting can be seen in table 2 below.

Table 2. An overview of feeding patterns

\begin{tabular}{|c|c|c|c|}
\hline \multirow[b]{2}{*}{ Variable } & \multicolumn{2}{|c|}{ Nutritional Status } & \multirow{2}{*}{$\begin{array}{c}\mathbf{p} \\
\text { valu } \\
\mathbf{e}\end{array}$} \\
\hline & $\begin{array}{c}\text { Stunting } \\
(\mathrm{n}=94)\end{array}$ & $\begin{array}{l}\text { Normal } \\
(\mathrm{n}=91)\end{array}$ & \\
\hline Giving MP-ASI & $94(100)$ & $91(100)$ & $\begin{array}{c}\mathrm{N} / \\
\mathrm{A}\end{array}$ \\
\hline Fruit & & & $\begin{array}{c}\text { Juice } \\
0.97\end{array}$ \\
\hline
\end{tabular}

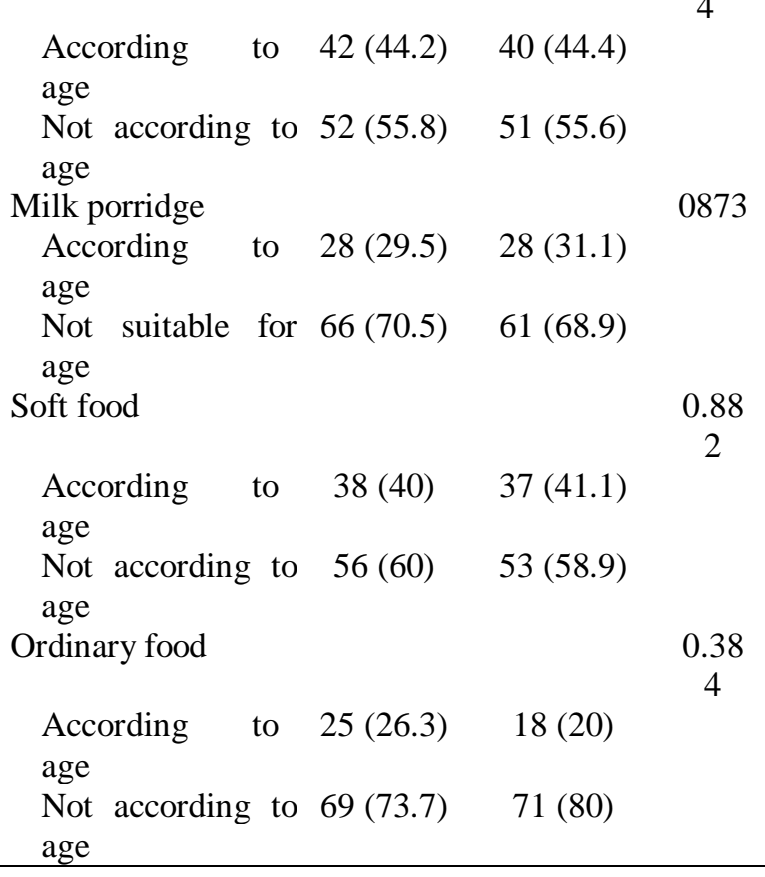

Table 2 is known that there is no relationship between feeding patterns with the incidence of stunting ( $p>0.05)$.

\subsection{Health Care Patterns}

An overview of health care patterns can be seen in the following tables.

Table 3. Description of health care patterns related to weighing children

\begin{tabular}{|c|c|c|c|}
\hline \multirow[b]{2}{*}{ Variable } & \multicolumn{2}{|c|}{ Nutritional Status } & \multirow[b]{2}{*}{$\begin{array}{c}\text { p- } \\
\text { value }\end{array}$} \\
\hline & $\begin{array}{l}\text { Stunting } \\
(\mathrm{n}=94)\end{array}$ & $\begin{array}{l}\text { Normal } \\
(n=91)\end{array}$ & \\
\hline $\begin{array}{l}\text { Defecateies } \\
\text { weighed } \\
\text { consecutively in } \\
\text { the last } 3 \text { months } \\
\text { weighed }\end{array}$ & & & 0.884 \\
\hline Regularly & $66(70.2)$ & $63(69.2)$ & \\
\hline $\begin{array}{l}\text { Weighted } \\
\text { irregularly }\end{array}$ & $28(29.8)$ & $20(30.8)$ & \\
\hline Not weighed & $0(0)$ & $0(0)$ & \\
\hline $\begin{array}{l}\text { There are no } \\
\text { records that } \\
\text { can be } \\
\text { trusted }\end{array}$ & $0(0)$ & $0(0)$ & \\
\hline \multicolumn{4}{|l|}{$\begin{array}{l}\text { Ordinary } \\
\text { children weighed } \\
\text { by }\end{array}$} \\
\hline Posyandu & $94(100)$ & $91(100)$ & \\
\hline PAUD & $0(0)$ & $0(0)$ & \\
\hline $\mathrm{RS}$ & $0(0)$ & $1(1.1)$ & \\
\hline Puskesmas / & $16(17)$ & $11(12.1)$ & \\
\hline $\begin{array}{l}\text { Pustu / } \\
\text { Polindes }\end{array}$ & & & \\
\hline Doctors & $5(5.3)$ & $3(3.3)$ & \\
\hline
\end{tabular}




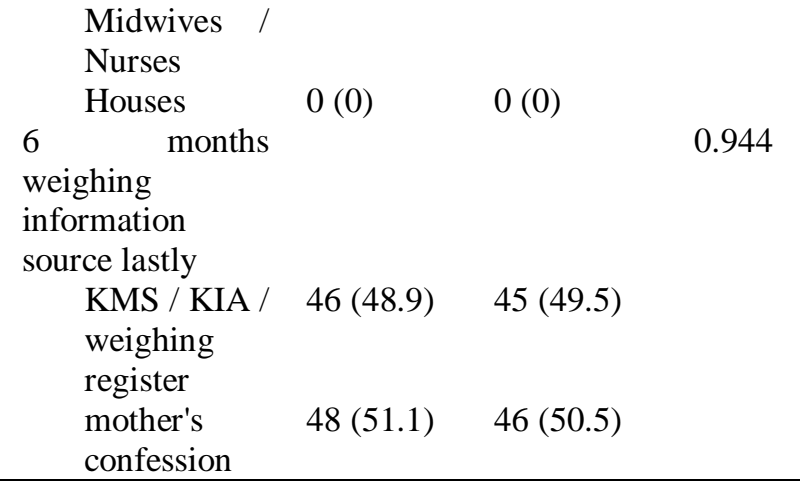

Table 3 shows that there is no relationship between health care patterns related to weighing children with incidence stunting ( $p>0.05)$.

Table 4 shows that there is no relationship between health care patterns related to immunization children withincidence stunting ( $p>0.05)$.

\subsection{Hygiene care patterns}

Table 5. Description of parenting hygiene related to family water source

\begin{tabular}{|c|c|c|c|}
\hline \multirow[b]{2}{*}{ Variable } & \multicolumn{2}{|c|}{ Nutritional Status } & \multirow[b]{2}{*}{ p-value } \\
\hline & $\begin{array}{c}\text { Stunting } \\
(\mathrm{n}=94)\end{array}$ & $\begin{array}{l}\text { Normal } \\
(\mathrm{n}=91)\end{array}$ & \\
\hline $\begin{array}{lr}\text { Source } & \text { of } \\
\text { drinking } & \text { water } \\
\text { family } & \end{array}$ & & & 0.531 \\
\hline Water spring & $15(16)$ & $9(9.9)$ & \\
\hline $\begin{array}{l}\text { Protected } \\
\text { water spring }\end{array}$ & $2(2.1)$ & $6(6.6)$ & \\
\hline $\begin{array}{l}\text { Open dug } \\
\text { well }\end{array}$ & $7(7.4)$ & $4(4.4)$ & \\
\hline $\begin{array}{l}\text { Protected } \\
\text { dug well }\end{array}$ & $3(3.2)$ & $3(3.3)$ & \\
\hline $\begin{array}{l}\text { Tap water / } \\
\text { PDAM }\end{array}$ & $57(60.6)$ & $63(69.2)$ & \\
\hline $\begin{array}{l}\text { Drill well / } \\
\text { pump }\end{array}$ & $3(3.2)$ & $1(1.1)$ & \\
\hline $\begin{array}{l}\text { Water river / } \\
\text { lake }\end{array}$ & $2(2.1)$ & $2(2.2)$ & \\
\hline $\begin{array}{l}\text { Gallon / } \\
\text { packaging } \\
\text { water }\end{array}$ & $5(5.3)$ & $3(3.3)$ & \\
\hline $\begin{array}{l}\text { Water used for } \\
\text { making milk / } \\
\text { milk porridge }\end{array}$ & & & $\begin{array}{c}0.924 \\
\text { Boiling }\end{array}$ \\
\hline $\begin{array}{l}\text { water } \\
\text { cooked }\end{array}$ & $78(83)$ & 77 (86.6) & \\
\hline $\begin{array}{l}\text { Cooked } \\
\text { water but }\end{array}$ & $11(11.7)$ & $\begin{array}{ll}9 & (9.9)\end{array}$ & \\
\hline $\begin{array}{l}\text { already cold } \\
\text {-cooked }\end{array}$ & $5(5.3)$ & $5(5.5)$ & \\
\hline
\end{tabular}

water

Based on table 5. There was no relationship between parenting hygiene related to family water sources and the incidence of stunting $(\mathrm{p}>0.05)$.

Table 6. Description of children's personal hygiene patterns

\begin{tabular}{|c|c|c|c|}
\hline \multirow[b]{2}{*}{ Variable } & \multicolumn{2}{|c|}{ Nutritional Status } & \multirow[b]{2}{*}{ p-value } \\
\hline & $\begin{array}{c}\text { Stunting } \\
(n=94)\end{array}$ & $\begin{array}{l}\text { Normal } \\
(\mathrm{n}=91)\end{array}$ & \\
\hline $\begin{array}{l}\text { When feeding } \\
\text { children, spoons, } \\
\text { plates and cups } \\
\text { of children are } \\
\text { washed first }\end{array}$ & & & 0.229 \\
\hline $\begin{array}{l}\text { Always } \\
\text { wash again }\end{array}$ & $86(91.5)$ & $86(94.5)$ & \\
\hline $\begin{array}{l}\text { Rarely } \\
\text { washed } \\
\text { again }\end{array}$ & $5(5.3)$ & $5(5.5)$ & \\
\hline $\begin{array}{l}\text { Never } \\
\text { washed } \\
\text { again }\end{array}$ & $3(3.2)$ & $0(0)$ & \\
\hline $\begin{array}{l}\text { Mother washed } \\
\text { her hands when }\end{array}$ & & & \\
\hline $\begin{array}{l}\text { giving a feeding } \\
\text { child }\end{array}$ & & & 0.974 \\
\hline Yes & $92(97.9)$ & $89(97.8)$ & \\
\hline No & $2(2.1)$ & $2(2.2)$ & \\
\hline $\begin{array}{l}\text { Children wash } \\
\text { their hands with }\end{array}$ & & & \\
\hline $\begin{array}{l}\text { soap before and } \\
\text { after meals }\end{array}$ & & & 0.528 \\
\hline Yes & $23(24.5)$ & $27(29.7)$ & \\
\hline No & $71(75.5)$ & $64(70.3)$ & \\
\hline
\end{tabular}

Based on table 6 There is no relationship between parenting hygiene related to family water sources and the incidence of stunting ( $p>0.05$ ).

Table 7. Description of parenting hygiene when defecate

\begin{tabular}{|c|c|c|c|}
\hline \multirow[b]{2}{*}{ Variable } & \multicolumn{2}{|c|}{ Nutritional Status } & \multirow{2}{*}{$\begin{array}{c}\text { P- } \\
\text { value }\end{array}$} \\
\hline & $\begin{array}{c}\text { Stunting } \\
(n=94)\end{array}$ & $\begin{array}{l}\text { Normal } \\
(\mathrm{n}=91)\end{array}$ & \\
\hline $\begin{array}{l}\text { Mother's child } \\
\text { defecate at }\end{array}$ & & & 0.270 \\
\hline Toilets & $46(48.9)$ & $43(47.3)$ & \\
\hline Gardens & $0(0)$ & $1(1.1)$ & \\
\hline Rivers & $43(45.7)$ & $36(39.6)$ & \\
\hline Trench & $5(5.3)$ & $11(12.1)$ & \\
\hline Wash hands with & & & 0.058 \\
\hline
\end{tabular}


soap after defecate

$\begin{array}{lll}\text { Yes } & 64(68.1) & 74(81.3) \\ \text { No } & 30(31.9) & 17(18.7)\end{array}$

Family toilet at

home

\begin{tabular}{lll} 
Yes & $36(38.3)$ & $40(44)$ \\
No & $58(61.7)$ & $51(56)$ \\
\hline
\end{tabular}

Based on table 7 There was no relationship between parenting hygiene related to defecation and the incidence of stunting $(\mathrm{p}>0.05)$.

\subsection{Psychosocial Parenting}

Table 8. Psychosocial parenting description

\begin{tabular}{|c|c|c|c|}
\hline \multirow[b]{2}{*}{ Variable } & \multicolumn{2}{|c|}{ Nutritional Status } & \multirow[b]{2}{*}{$\begin{array}{c}\text { p- } \\
\text { value }\end{array}$} \\
\hline & $\begin{array}{c}\text { Stuntin } \\
\mathrm{g} \\
(\mathrm{n}=\mathbf{9 4})\end{array}$ & $\begin{array}{l}\text { Normal } \\
(\mathrm{n}=91)\end{array}$ & \\
\hline Psychosocial Pattern & & & Care \\
\hline Category & & & 0.765 \\
\hline - Low & $\begin{array}{c}58 \\
(61.7)\end{array}$ & $\begin{array}{c}52 \\
(57.1)\end{array}$ & \\
\hline - $\quad$ Medium & $\begin{array}{c}34 \\
(36.2)\end{array}$ & $\begin{array}{c}36 \\
(39.6)\end{array}$ & \\
\hline - $\quad$ Good & $2(2.1)$ & $3(3.3)$ & \\
\hline
\end{tabular}

Table 8 shows that there is no correlation between psychosocial parenting and the incidence of stunting $(p>0.05)$. there is still a low level of psychosocial parenting between stunting children and normal children.

\subsection{Human Resources}

Human resources can be seen in table 9 below.

Table 9. Nurturing human resources

\begin{tabular}{|c|c|c|c|}
\hline \multirow[b]{2}{*}{ Variable } & \multicolumn{2}{|c|}{ Status Nutrition } & \multirow[b]{2}{*}{$\begin{array}{c}\mathbf{p} \\
\text { value }\end{array}$} \\
\hline & $\begin{array}{c}\text { Stunting } \\
(\mathrm{n}=94)\end{array}$ & $\begin{array}{l}\text { Normal } \\
(\mathbf{n}=91)\end{array}$ & \\
\hline \multicolumn{4}{|l|}{$\begin{array}{l}\text { HR who often care } \\
\text { for }\end{array}$} \\
\hline Mother & $90(95.7)$ & $\begin{array}{c}85 \\
(93.4)\end{array}$ & $\mathrm{N} / \mathrm{A}$ \\
\hline Husband & $1(1.1)$ & 0 & \\
\hline $\begin{array}{l}\text { Grandmother / } \\
\text { grandfather of child }\end{array}$ & $3(3.2)$ & $5(5.5)$ & \\
\hline $\begin{array}{l}\text { Mothers who are } \\
\text { immature }\end{array}$ & 0 & $1(1.1)$ & \\
\hline $\begin{array}{l}\text { HR who replace } \\
\text { mothers if there is no }\end{array}$ & & & \\
\hline husband & $19(20.2)$ & $\begin{array}{c}29 \\
(31.9)\end{array}$ & 0.101 \\
\hline Grandmother & $34(36.2)$ & 29 & \\
\hline
\end{tabular}

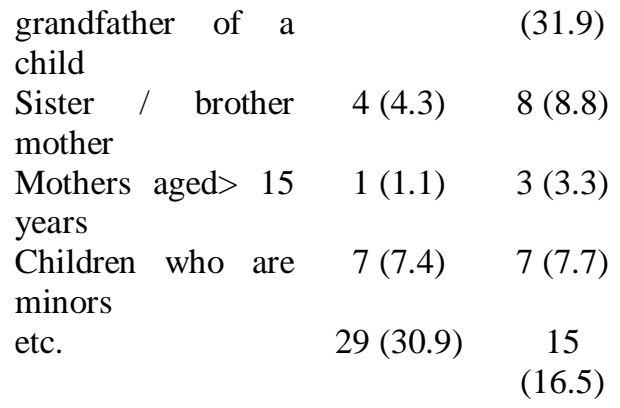

Replacing work household yes

None

$\begin{array}{ccc}30(31.9) & 46 & 0.015 \\ & (50.5) & * \\ 64(68.1) & 45 & \end{array}$

Involvement of husband

Not participating

$\begin{array}{cc}10(10.6) & 11 \\ 64(68.1) & (12.1) \\ & 59 \\ 19(20.2) & 21 \\ & (23.1)\end{array}$

0.729

In a certain period of time

Have a big role

$1(1.1)$

0

Table 9 shows that there is a relationship between the existence of human resources that replace domestic work and the incidence of stunting ( $p<0.05)$. However, there is no relationship between human resources who often care, substitute human resources if the mother does not exist and the involvement of the husband with the incidence of stunting.

Table 10. Length of day average Mother caring for children

\begin{tabular}{|c|c|c|c|}
\hline \multirow[b]{2}{*}{ Variables } & \multicolumn{2}{|c|}{ Nutritional Status } & \multirow[b]{2}{*}{$\underset{\text { value }}{\mathbf{p}}$} \\
\hline & $\begin{array}{c}\text { Stunting } \\
(n=94) \\
\text { Mean } \pm \\
\text { SD }\end{array}$ & $\begin{array}{c}\text { Normal } \\
(n=91) \\
\text { Mean } \pm \\
\text { SD }\end{array}$ & \\
\hline $\begin{array}{l}\text { Breastfeedin } \\
\text { g (hours) }\end{array}$ & $0.73 \pm 0.28$ & $0.62 \pm 0.42$ & 0.553 \\
\hline $\begin{array}{l}\text { Preparing } \\
\text { food } \\
\text { hours })\end{array}$ & $0.61 \pm 0.59$ & $0.36 \pm 0.06$ & $\begin{array}{c}0.005 \\
*\end{array}$ \\
\hline $\begin{array}{l}\text { Feeding } \\
\text { children } \\
\text { (hours) }\end{array}$ & $0.48 \pm 0.39$ & $0.34 \pm 0.06$ & 0.140 \\
\hline $\begin{array}{l}\text { Bathing and } \\
\text { dressing } \\
\text { children(hou } \\
\text { rs) }\end{array}$ & $0.37 \pm 0.02$ & $0.15 \pm 0.09$ & $\begin{array}{c}0.002 \\
*\end{array}$ \\
\hline $\begin{array}{l}\text { Helps during } \\
\text { defecate and }\end{array}$ & $0.30 \pm 0.06$ & $0.12 \pm 0.02$ & $\begin{array}{c}0.003 \\
*\end{array}$ \\
\hline
\end{tabular}




\begin{tabular}{llll}
$\begin{array}{l}\text { urinate } \\
\text { (hours) }\end{array}$ & & & \\
$\begin{array}{l}\text { Carrying } \\
\text { children } \\
\text { (hours) }\end{array}$ & $1.19 \pm 1.12$ & $0.79 \pm 0.02$ & $\begin{array}{c}0.013 \\
*\end{array}$ \\
$\begin{array}{l}\text { Playing with } \\
\text { children } \\
\text { (hours) }\end{array}$ & $2.66 \pm 1.94$ & $3.18 \pm 2.04$ & 0.081 \\
$\begin{array}{l}\text { Putting the } \\
\text { child to } \\
\text { sleep (hour) }\end{array}$ & $0.66 \pm 0.03$ & $0.71 \pm 0.05$ & 0.709 \\
$\begin{array}{l}\text { Looking for } \\
\text { treatment }\end{array}$ & $0.24 \pm 0.01$ & $0.19 \pm 0.06$ & 0.419 \\
and \\
treatment \\
$\begin{array}{l}\text { when sick } \\
\text { hours) }\end{array}$ & & & \\
\hline
\end{tabular}

Table 10 shows that there are differences in the average length of preparing food, bathing and putting on children's clothes, helping during defecation and BAK and carrying children in stunting and nonstunting children $(p<0.05)$. But there is no difference in the average length of giving ASI, providing food for children, playing with children, sleeping children and seeking treatment and care when sick in stunting and non- stunting children ( $\mathrm{p}>0.05)$.

\section{Discussion}

\subsection{Feeding Patterns Parenting style of}

feeding children in breastfeeding $44.8 \%$ ofchildren stunting who were given formula milk and $49.1 \%$ of normal children were given formula milk.

If you look at the picture of parenting eating children at the study site, it still seems not good, especially inchildren stunting. The implementation of a good diet by the mother or substitute for a caregiver is one that determines the amount of theintake child's. Ultimately it relates to the nutritional status of children (Engle, 1995; Masrul, 2005).

\subsection{Health Care Patterns}

From the results of the study, onethird of the samples ofchildren stunting and normal children were not regularly weighed in Posyandu / Puskesmas and less than half there was no proof of payment in the KIA book. Based on this, it turns out that there are still many children who do not monitor growth and development properly (Soetjianingsih, 1998). Of course this has an impact on efforts to prevent stunting. Giving immunization by giving vitamin A is relatively better.

\subsection{Hygiene Care Patterns}

From drinking water sources, the family ofchildren stunting and normalis almost the same around $51-56 \%$. This means that there are half of them that cannot be ascertained that the source of drinking water is good. If drinking water is not clean the risk of diarrhea will be high. Early life in 2 years with stunting has a history of diarrhea> 5 times / year (Verley KG et al., 2011).

To defecate more than $45 \%$ ofchildren stunting and $36 \%$ of normal children throw in the river. This situation shows that the condition of their cleanliness and hygiene is still lacking. Availability of latrines in households is still lacking. $61.7 \%$ ofchildren stunting do not have latrines at home and $56 \%$ of normal children do not have latrines at home.

\subsection{Psychosocial Care Patterns}

from measurements with HOME on child psychosocial stimulation are relatively less than normal with a score of $<40$. The results of structured observations by pediatric psychiatrists as many as 15 people, samples of mother and child relationships there also showed a lack of interaction and stimulation of the mother.

From the results of Mc Gregor's study in Guatemala 1987, the results of adequate stimulation showed considerable benefits for child development (Jalal, 2008). The low psychosocial stimulus certainly has an impact on the growth of their children.

\subsection{Nurturing $H R$}

Most of the primary caregivers are mothers, both in normal children andchildren stunting. The husband is quite instrumental in replacing parenting if the mother is absent from a normal child compared to achild stunting. In normal children, there are substitutes for maternal housework compared tochildren stunting. Parenting resources, substitutes for 
maternal work are important factors in the child's growth process (Engle PL etL.., 1997).

From this study it was found that there was no difference in the length of care between stunting children and normal children. Husband's support in parenting between the two groups of children is not much different. But substitutes for maternal work are very important for child development (Engle PL et al., 1997).

\section{CONCLUSION}

- The administration of MP-ASI is almost no different from the group stunting compared to normal children.

- Good parenting for stunting children and normal children are still lacking.

- The health care pattern of stunting children and normal children is still lacking.

- Parenting psychosocial stimulation of stunting children and normal children is still not good.

- Most of the main caregivers are mothers, both in normal children and stunting children.

- The husband is quite significant in replacing parenting if the mother is absent in normal child compared to stunting child.

- Substitution of mother's work during parenting is very important.

- From this study it was found that there was no difference in the length of care between stunting children and normal children. 


\section{REFERENCES}

Black R.E., Victora C.G., Walker S.P. Maternal and child undernutrition and overweight in lowincome and middle-income countries. Lancet. 2013;382:427-451.

Bhutta, Z.A., Das, J.K., Rizvi, A., et al., 2013. Evidence-based interventions for improvement of maternal and child nutrition: what can be done and at what cost? Lancet 382, 452-477.

de Onis M., Onyango A., Borghi E. Worldwide implementation of the WHO Child Growth Standards. Public Health Nutr. 2012;15:1603-1610.

Engle P.L,Menon P., Haddad L. 1995. Care and Nutrition: Concepts and Measurement International Food Policy Reseacrh.

Henmughan HB, Mc Gregor SG. 2003. Refondasi Pertumbuhan Usia. Gizi Kesehatan Masyarakat EGC. Hal 206 - 307.

Henmughan HB, Mc Gregor GG. 2005. Pemberian ASI dan Pengasuh Terhadap Tumbuh Kembang Anak Dalam: Gizi Kesehatan Masyarakat. EGC. Hal: 300 - 310.

Jellife D.B. 1989. Community Nutrional Assessment. Oxford University Press. New York.

Jonssan U. 1983. Nutrition and The United Nations Convention and The Rights of The Child Occasional Papers. Child Right Series No.5.

Kemenkes. 2007. Riset Kesehatan Dasar

Kemenkes. 2010. Riset Kesehatan Dasar

Masrul 2005. Kajian Peranan Sumber Daya Pengasuhan Terhadap Tumbuh Kembang Bayi Usia 6 - 12 bulan Pada Keluarga Etnik Minangkabau di Pedesaan Provinsi Sumatera Barat. Disertasi: Program Pasca Sarjana Universitas Airlangga.

Murray C.J. Shifting to sustainable development goals-implications for global health. N. Engl. J. Med. 2015;373:1390-1393.

Semba R.D. Nutrition and development: a historical perspective. In: Semba R.D., Bloem M.W., editors. Nutrition and Health in Developing Countries. second ed. Humana Press; Totowa, NJ: 2008. pp. 1-31.

Soetjimipsil, Ranuh. 1998. Strategi Kelangsungan Hidup Anak Dalam; Tumbuh Kembang Anak. Hal: $127-140$.

UNICEF/World Health Organization/World Bank Group . United Nations Children's Fund, World Health Organization, and World Bank Group. 2015. Levels and Trends in Child Malnutrition: Key Findings of the 2015 Edition.([ http://www.who.int/nutgrowthdb/jme brochure2015.pdf?ua=1] 